Bulletin de la Société Royale des Sciences de Belgique, Vol. 85, 2016, p. 1588 - 1600

\title{
Half an analytical look at the history of the emergence of Concrete poetry
}

\author{
Nusratollah Din Mohammadi KARASFI ${ }^{1}$ \\ ${ }^{1}$ Department of Persian literature, Khodabandeh Branch, Islamic Azad University, Khodabandeh, \\ Iran \\ Email: dnosratollah@yahoo.com
}

\begin{abstract}
The concrete poetry is regarded as the modern poetic movements in Europe and Iran. Concrete poetry is one of the written deviations and foregrounding is associated with irregularity of poetry, graphic and sometimes calligraphic lines. In this poetic movement, the written structure is selected in such a way that the form, the structure and the combination of words, the interrupted structure of the words, the degraded form of the words into the forming letters has created visual images that play an important role in transferring the motif to the audience. The author in this article aimed to review analytically the formation history of concrete poetry in Europe and Iran from the beginning until now. the history of visual communication is very old that dates back to the very remote times. Guillaume Apollinaire $(1880-1918)$ played an important role in the emergence of concrete poetry. After 40 years, Apollinaire ultimately paved the way for concrete poetry by creating kind of visual poetry namely Calligram. Apollinaire enjoyed the experience of eastern poets in addition to western poet. in 1958, the basic principles of concrete poetry were compiled and again the Brazil was the flagship of this movement. In the early 60s, Eugen Gomringer published the concrete works of the poets in different countries of the world after the foundation of International Movement of concrete poetry. In Iran, Tahereh Saffarzadeh, a theorist and contemporary researchers, was the founder of the concrete poetry in Persian language. After Tahereh Saffarzadeh, Esmail Nooriala, a contemporary poet and critic, was regarded as the founder, promoter of concrete poetry in Persian language and literature.
\end{abstract}

Keywords: Defamiliaraization, Deviation, concrete poetry, Guillaume Apollinaire, Eugen Gomringer, T Saffarzadeh.

\section{Introduction}

Concrete poetry was formed six decades age in Europe (Switzerland) while there is much precedent for its similar examples in classical literature of many countries including ancient Greece, Iran, India, China and so forth. In the fifth century Sh, there was a type of poetry called "acrostic poetry". When we compare its different species including verses shaped as a tree, a bird, and geometric forms, the several similarities are revealed between them. In addition, many similarities exist between the traditional Iranian poetry and a type of concrete poetry known as "Calligram". The several similarities between the concrete poetry in Europe and various species 
of acrostic poetry in Iran indicates the inspiration of the Europeans, especially the French, from the traditional Persian poetry. Since in the literary interactions between Iran and France in the last century, our literature, in addition to be influenced by the French literature, influenced the French authors and poets in various aspects. Most of the scholars in western world knew that there is a country named Iran in the eastern world which has the rich sources of knowledge, wisdom, spirituality and purity and they have repeatedly mentioned these concept in the works (Azar, 2008: 294). For example, after establishing the first school of eastern languages in France in 1796 by Louis Mathieu Langls (1774-1823), many valuable Iranian literary works were translated into French. These translations provided the familiarity and inspiration of the Europeans, particularly the French from the literature of the east including Iranian literature. Therefore, in recent century, especially in the nineteenth and twentieth centuries we were influenced by French poets and writers including Victor Marie Hugo, Taru Brothers, Jean Lahore, Armand Renaud, Tristan Klingsor, André Gide, and dozens of other poets including Iranian writers and poets, particularly Hafez and Saadi Shirazi, Khayyam Neyshaburi and Attar Neyshaburi, Nizami Ganjavi and other Iranian poet an scholars. One of the European's impression of Iranian literary works was the story of European poets' impression, including the French poets, of the physical and graphical structure of concrete poetry in traditional Persian literature including the graphical shape of a tree, a bird and... In order to create concrete poem. The initial germ of the concrete poetry was to be found with the Calligrams by the French poet Guillaume Apollinaire (1918). Four decade after this date, in 1953, the term "concrete poetry" was first introduced by forming the group of Brazilian concrete poetry including Eugen Gomringer called the father of concrete poetry. It should be noted that in Switzerland, the concrete poetry was introduced with the help of Eugen Gomringer. In Persian literature, Tahereh Saffarzadeh, Iranian poet and researcher, was the first poet who composed poetry in concrete style following the teachings of English and Americans poets and spoke about the principles and philosophy of the emergence of concrete poetry. After her, Esmail Nooriala was considered as the founder and promoter of the concrete poetry. Although few studies have been conducted on concrete poetry, there is no systematic study which contained, analytical critique, critical and comparative review and describe the history of this poetic movement in World literature and Iranian literature. Therefore, this study aimed to explore the history of this poetic movement in European literature and Iranian literature while criticizing and analyzing comprehensively this poetic movement.

\section{Research background}

Few studies have been conducted on concrete poetry by the researchers so that the most important can be mentioned as the following:

Tahereh Saffarzadeh in her book "Movement and yesterday" present an introduction on concrete poetry and its background. Mostafa Alipour in his book "Linguistic structure of today's poetry" 
as well as in "Linguistics" introduced the concrete poetry and presented some examples. Shams Langarudi in his book "Analytical history of modern poetry" described the characteristics of concrete poetry, derived from the New Wave poetry and Hajm Poetry ${ }^{1}$, while introducing the characteristics of New Wave poetry. Kavoos Hasanli in his book "Species of innovation in contemporary poetry" while referring to concrete poetry. Mohammadreza Rouzbeh in his book " Contemporary Iranian Literature", presented briefly the concrete poetry. Other sources addressing the concrete poetry can be mentioned as the following:

1. The book "Theory of poetry from New Wave poems to Love poems" as well as The article "In Search of identity of the concrete poetry" by Ismail Nooriala.

2. "Music poetry book" written by Mahmoud Falaki

3. The article "Concrete Poetry and in memory of Tahereh Saffarzadeh" by Soheil Mahmoudi.

4. The article "A review on the portrayal and visualization in plastic poetry" by Majid Yeganeh.

5. The article "Reading the Claus Bremer's concrete poems" by Mohammad Azarm.

6. The article "Contemporary concrete poetry and other sources" (cited in the references of the article) by Mazdak Panjei.

\section{Research Method}

In this study, the researcher attempted to explore the history of this poetic movement in European literature and Iranian literature while this poetic movement by taking advantage of integrative methods of literary criticism as well as library method and historical criticism.

\section{Discussion}

\subsection{Concrete poetry}

The word "concrete" is originally an English word which means objective, tangible, visual, capable of being perceive by the senses (Bateni, 1999: 161), and formed by the coalescence of particles (Simpson, 1972: 391), strong, hard, physical, real, tangible (Mahmoudi, 2008:1). Concrete poetry is one of the most modern poetic movements dated back to nearly six decades in European literature and five decades in Iranian literature. This poetry is considered as one of the foregrounding (Shamisa, 2004: 162) and deviations (ibid) or extra regularity (Leech, 1969: 62) whose structure is developed by the combination of poem and graphics. In fact, concrete poetry is the point of intersection between the auditory art of poetry and visual art of poetry that produce pristine and pleasant Synesthesia in the poem. As the poet combines these two auditory and visual senses when versifying a poem, the audience also use these two senses while understanding the poem. In concrete poetry, the poet indicate his/her desired concepts in the form of an image. An image that presented in the written form of letter and words used in the poem, and sometimes the image can be the result of combining the collocation of words in the

\footnotetext{
${ }^{1}$ Hajm is a Persian term referred to the amount of 3-dimensional space occupied by an object.
} 
poem. It should be noted that sometimes the images in concrete poetry are formed by the repetition of slashed-words or decomposed letters of a word. In this poetic movement, the poet attempts to rely on visual texture instead of verbal texture by pushing the word toward the image or by association of the image through the words (Gharibi, 13:12). In these poems, the physical representation of the words is in fact the accurate image of their subjective meaning. The poet creates an image rather than writing the meaning of the poem. This poetic movement were pledged to literature in the one hand and to graphics on the other hands. Therefore, the concrete poetry plays an intermediate role in the art of writing, painting and sometimes in the art of calligraphy. In concrete poetry, the words speak and the images show the concepts in the poem. The words and images are regarded as two wings that convey the message of the poet. For example, Esmail Shahroudi in the following poem, wrote the word "بُهنا" (meaning width) extremely wide in order to visualize the physical structure and graphical shape of the word through foregrounding and to portray the dignity of the poet and the dignity of audience's idea by taking advantage from the characteristics of deviation.

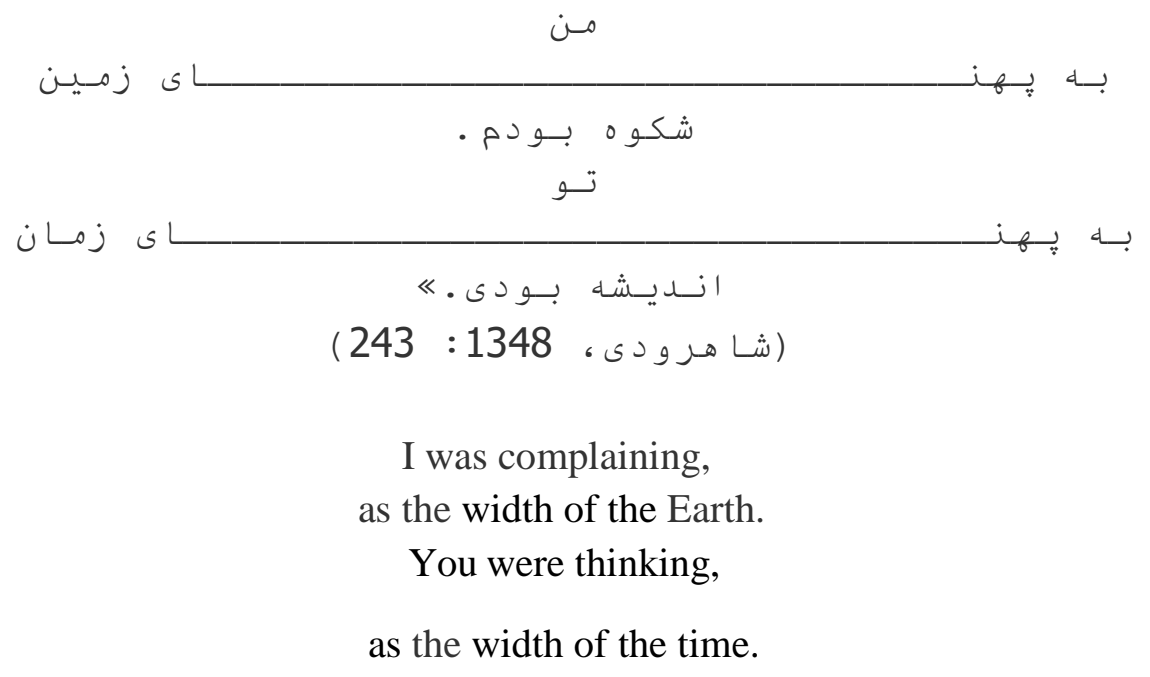

(Shahroudi, 1969: 243)

Or as another example, K. Monshizadeh in the following poem titled "Purple continent", with a break in the written form of the word "Hiroshima", after the atomic bombing of Hiroshima disaster reminded (as well as the city of Nagasaki) Japan on August 6 1945, destruction of Hiroshima and bodies scattered picture on canvas the city this deviation in writing, is depicted. Obviously, the effectiveness of this form of linguistic broken concrete poetry

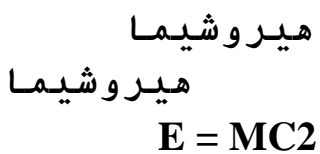




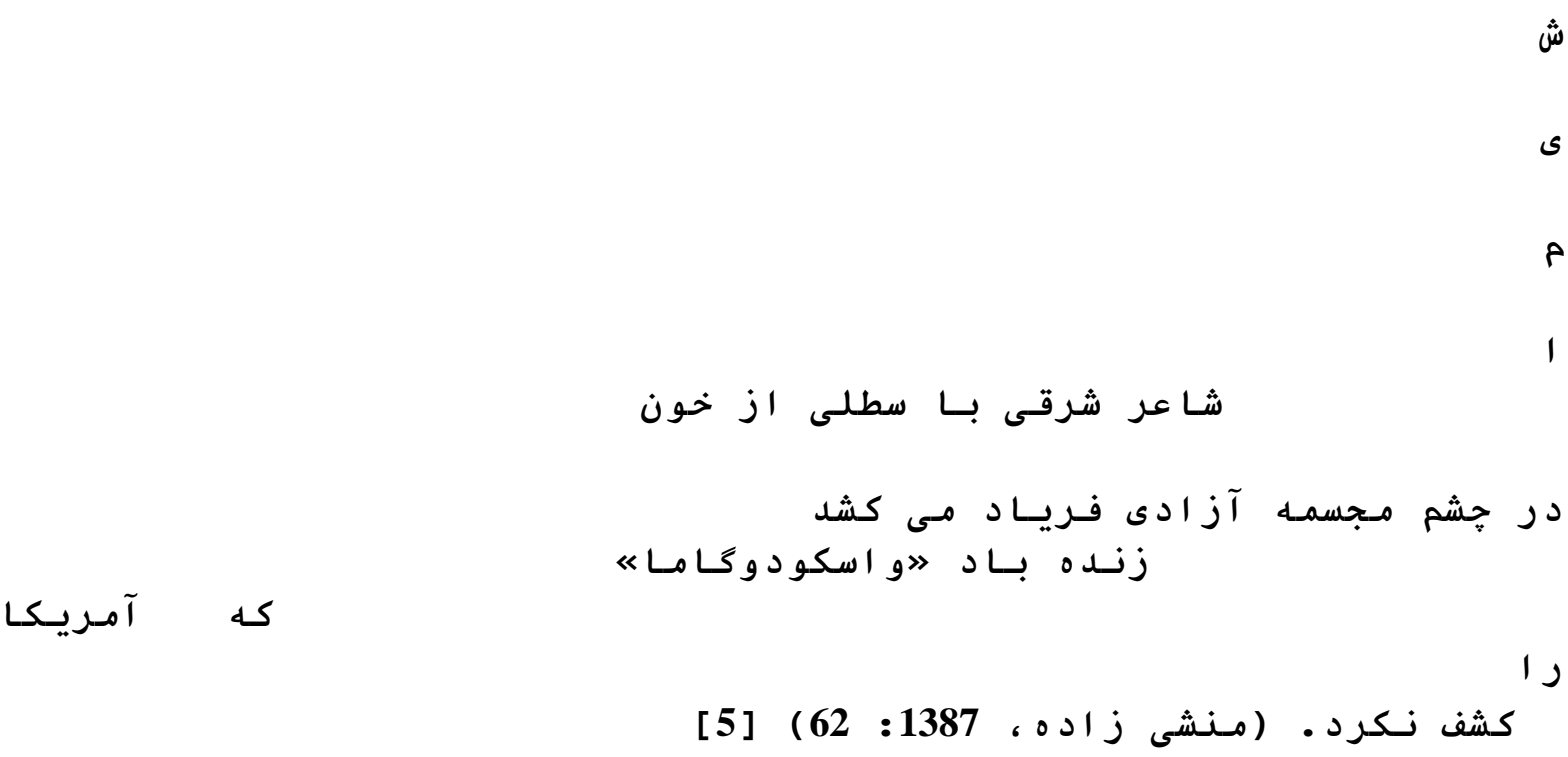

Hiroshima

Hiroshima

$$
\mathrm{E}=\mathrm{MC} 2
$$

Hi

r

0

$\operatorname{sh}$

$\mathrm{m}$

$\mathrm{a}$

The Eastern poet, with a bucket of blood,

Shouts at the Statue of Liberty s eye,

Long life the "Vasco de Gama "

Who did not discover The America's. (Monshizadeh, 1387: 62)

The concrete poetry is interpreted as visual poetry (visualization) in Persian language. It should be also noted that the Iranian researchers have referred the concrete poetry with various terms, 
other than the term "concrete poetry", among which can be mentioned as the following: Visual poetry, plastic poetry, concrete poetry, visual-auditory poetry, acrostic poetry, pattern poetry, tangible poetry, while the common and appropriate equivalent for concrete poetry is "concrete poetry". Esmail Nooriala states on the philosophy of this nomenclature that, "I decided to find a new name for the remnants of New Wave poetry, simultaneously with the presence of the Hajm poetry. What I have got and also presented in Ferdowsi workshop was the name "concrete poetry". Therefore it can be said that the New Wave poetry has come to the end since 1971 and this poetic movement was divide into two style namely " concrete poetry" and "Hajm poetry" (Nooriye ala, 1994: 139). The emergence of this poetic movement is the beginning for the combination of poetry with other visual arts including Sculpture, architecture, photography, cinema, the internet and so forth which are presented in the form of modern poetic movements including concrete poetry, digital poetry, visual poetry, sound democracy, (Saffari, 2006: 408), electronic poetry (Azarm, 2007: 4) and cinema (Panjei, 2012: 9). Visualization of the poem was first performed by displacing the lines in the horizontal and vertical axis and then the poem is put at the process of visualization. After that the poet enters gradually the image and painting in the poem and place the painting of a given word rather than placing the word itself. The poet does not rely only in this form of composing a poem and enters the image of the word independently in the poem and combines the media. This characteristics in poetry is regarded as the peak for the visualization of the poetry. Critics and scholars have called part of this visualization as concrete poetry (Gharibi, 2012: 2).

\subsection{The history of concrete poetry in world literature}

In a broad perspective, it should be said that the history of visual communication is very old that dates back to the very remote times. The first stone engravings and graffities of troglodyte is regarded as the first visual and graphical languages that date back to at least seven thousand years ago. The internal thoughts were expressed through visual signs that was considered as the first human efforts for writing. Therefore, in the broad sense, the history of literature was more linked with the history of painting and image, since the first samples of handwriting was imaging; Sumer, China and Crete presented the samples in the form of image. In Iran so far, we had the samples of handwritings in which poetry, it shows what can be said. The oldest samples of visual poetry can be found in the ancient poems of China and Japan: since the poets of that time created inscriptions using their own pictograms. Such prosodies still can be found in Iran. While apart from the eastern sources of visual poetry (China, Japan and Iran), the oldest examples in western world can be seen in Greek literature and in the works of the poets of pastoral poetry, especially in the poems of "Simmias of Rhodos"2. for example, Theocritus"

\footnotetext{
2 a Greek poet and grammarian of the Alexandrian school, which flourished under the early Ptolemies. He was earlier than the tragic poet Philiscus of Corcyra, whose time is about $300 \mathrm{BC}$, at least if we accept the assertion of Hephaestion (p. 31), that the choriambic hexameter, of which Philiscus claimed the invention, had been previously used by Simmias.

${ }^{3}$ the creator of ancient Greek bucolic poetry, flourished in the 3rd century BC.
} 
panpipes that is far more ancient than Apollinaire's handwriting (Shurel, 2007: 138). It should be noted that the relation between subjecting concepts and writing were very poor at that time. The visual forms can only convey the general concepts and the expression of details was not possible. For example, they draw seven sheep in order to express the number of sheep. Tis was the primary method for communication through visual signs and symbols. In other words, it is the use of descriptive patterns and visual signs similar to the paintings which is called pictography by the researchers. The difference between pictography and painting was that in pictography only the things that were important for communication were to be drawn and therefore it is not addressed to the aesthetic aspects of the work which is important in painting (Bagheri, 1991: 115). After the invention of writing system, it was these images that were replaced by human words, and therefore human being learned to perform better in conveying the meaning and concepts using words, image or paintings. Hence, the writing system along with image (painting) was considered as an element (Honarmandi, 1971: 514) that plays a significant role in conveying the meaning.

\subsection{The history of concrete poetry in European literature}

In Europe, the versification of concrete poetry in English Literature was began with the book "The Arte of English Poesie" by Puttenham (1529-1590). In the Renaissance period, a number of poets versified concrete poems including George Herbert. In the poems of such poets, the shape created on the paper determined ad summarized the subject of the poem. The well-known example can be George Herbert's "Easter Wings" and "The Altar". As it can be seen in the following poem (Easter Wings), the pattern of the lines in the verse is in the shape of wings.

Lord, who createdst man in wealth and store

Though foolishly he lost the same

Decaying more and more

Till he became

more poor

with you

$\mathrm{O}$ let me rise

As larks, harmoniously

And sing this day thy victories

Then shall the fall further the flight in me. (Dad, 19996: 195)

In the second half of the eighteenth century, Gotthold Ephraim Lessing (German writer, philosopher, dramatist, publicist and art critic (1729-1781) addressed to the boundary between 
painting and poetry and wrote Laocoon by referring to the Simonides' aphorisms (556-467 B.C.). He considered painting as visual arts including both sculpture and particularly painting (Shorel, 2007: 138). After the Great revolution in France (1789) and establishing the knowledge of social order, it was decided to dismantle the punctuation marks, correct the spelling, write and create the "new language". This language policy, following the Linguistic thought of the Enlightenment, indicated the mediating elements in the new concept of "citizenship". In this era, the poem "A throw of the dice" versified by Stephane Mallarme (1897) and later in 1918 the Calligrams by Guillaume Apollinaire can be mentioned. In 1912 to 1917, the movement known as "Imagism" occurred in English and American poetry which sought clarity of expression through the use of precise images. The imagists emphasized on the imagery and the attention to the brevity and compactness of the poem that can be an important and effective factor in the emergence of the concrete poetry. For example, "The Red Wheelbarrow" which is a poem by American modernist poet and physician William Carlos (Hosseini, 1992: 85). The Cubism painting style (1906) that was emerged almost simultaneously with the school of Imagism, after reaching to the area of literature, has played a significant role in the emergence and development of the concrete poetry. In Cubist painting, the painter, first, attempts to draw, decompose and separate the pictorial elements he/she wants, rather than re-building or imitating the dimensions or perspectives existed in the nature, and then attempts to combine them in a new form and shape. This method in painting results in the geometric shape of the natural forms (Mirsadeghi, 1994: 222). Some researcher believed that the ideas of Wittgenstein (an Austrian philosopher 1889-1951), particularly his theory of "language games" appeared to be effective for the poets of concrete poetry. Wittgenstein believed that we transfer the words from metaphysical language game to ordinary language game (Ahmadi, 1995: 282). Despite of all these backgrounds and effective factors, the concrete poetry was not officially announced until the mid-twentieth century.

Guillaume Apollinaire (1880 - 1918) played an important role in the emergence of concrete poetry, since all the previous experiences of the European poets in versifying visual poems had reach the point of unity for him. After 40 years, Apollinaire ultimately paved the way for concrete poetry by creating kind of visual poetry namely Calligram. Therefore, his Calligrams was regarded as an introduction to the emergence of the concrete poetry. The Calligram is a visual poetry written with a beautiful calligraphy and the arrangement of the phrases and the sentences forms the graphical images. This graphical images has conveys a large part of the meaning of the verse. It should be noted that Apollinaire published his Calligram poems in the collection of the same name "Calligram" in 1918. Apollinaire was influenced by several factors in creating his Calligrams. On the one hand, he had all the previous experiences of the Europeans poets in earlier period in the shadow of his broad and deep studies. On the other hand, He was influenced by his painter friend, Picasso" and other French painters. He used the "model" in some of his graphical poems among which the model of Picasso's thumb can be mentioned. Apollinaire in his book "Cubist painters" considers the work of the cubist painter and poet as something that is united and believes that they both seek to draw a new plan from the 
manifestation of nature and to broaden the limits of human imagination more than addressing to its outer shell by transferring the inner sense of reality (Anousheh, 1997: 117). Apollinaire enjoyed the experience of eastern poets in addition to western poet. He was influenced by the classical Iranian poets in versifying his Calligrams. In particular, he was influenced by Iranian acrostic poem in all its shapes including a tree, a bird, a circle and so forth. Mr. Hasan Honarmandi in the book "The foundation of new poetry in France" by putting together the samples of different species of versification of previous Persian poets Guillaume Apollinaire's poems and his inspiration from the acrostic Persian poetry, said: An expert of Persian literature has the right to consider the similarity between concrete poetry and acrostic Persian poetry and to assume that Apollinaire has analyzed the manuscripts of eastern literary works in the National Library of France and was inspired from the Persian works (Honarmandi, 1971: 514). In addition, Tahereh Saffarzadeh also refers to the background of concrete poetry in the traditional Iranian poetry and says, “If we consider the Apollinaire's Calligram as the basis of concrete poetry, the calligraphers and writer of amulets and prayers have done such effort earlier (Saffarzadeh, 1986: 161). Alireza Panjei also considers Apollinaire as the imitator of Iranian acrostic poetry and says, "I think the origins of concrete poetry goes back to the acrostic verse with the shape of tree in the book "Lexicon in the standards of Persian poetry" and then the influence of the European poetry (particularly the poetry in France) can be attributed to Iran. In addition, Apollinaire was also strongly influenced by the Iranian literature and culture and it can be said that his prose have been borrowed from the acrostic verse (shaped poems ) in the

\subsection{The emergence of concrete poetry in the mid twentieth century in Europe}

In the mid-twentieth century in the 60s, after the formation of international movement of Concrete poetry, the term "concrete poetry" was first known and after compiling its anthology, it was developed in 1958. The following reasons can be named for the emergence of the concrete poetry:

Fundamental changes in the area of political, social, scientific, cultural nature, and transformation of in various areas including the emergence of media and communication networks and the internet in the world, the invention of computers and super computers and its dramatic effects on notification events. The launch of sites and blogging for news and literary and artistic content, Satellite TV, Bluetooth, mobile phone, Pluralism and diversity,

Indolence and hedonism, derogation of idealistic ideas and values and the values existed in poetry of the forties and fifties in the late sixties, the replacement of language game rather than the previous themes in poems, the replacement of individualism and attention to detail rather than the previous philosophical, epistemic and literary micro thinking, the common and personal interpretation for the avoidance from the literature and the attention to the ordinary relationships of ordinary people and ultimately the replacement of the objective and visual elements in the poems rather than abstract concepts. In 1952, a Brazilian poet named Décio Pignatari established 
the Brazilian concrete poetry with the help of several other poets. In addition, in Bolivia another poet named Eugen Gomringer has joined to their movement. In summary, the first "concrete poetry exhibition" were held in Sao Paulo ( the largest city in Brazil) in 1956, four years after the formation of concrete poetry movement. This exhibition was inspired by the works of a Brazilian artist Carlos Drummond de Andrade. Two years after the exhibition, in 1958, the basic principles of concrete poetry were compiled and again the Brazil was the flagship of this movement. In the early 60s, Eugen Gomringer went to Switzerland and published the concrete works of the poets in different countries of the world after the foundation of International Movement of concrete poetry. In addition, He took the responsibility of developing the concrete poetry by describing this poetic movement. The activities of Eugen Gomringer in the promotion and development of the concrete poetry made him the father of concrete poetry in Switzerland. It is worth mentioning that the concrete poetry in Switzerland was developed simultaneously with the concrete poetry in Sweden by Oyvind Fahlstrom. After that, the poets of America, Mexico, Japan, Germany, Czechoslovakia and England showed the trend toward the concrete poetry. Germany was also regarded as one of the centers for the development of concrete poetry. The concrete poetry received a great importance by the effective establishment of concrete poetry in New Germany. From 1957 to 1959, a group of people called "the Darmstadt circle" published journals, samples and the first anthology of concrete poetry. Claus Bremer (German playwright) was the head of the Darmstadt circle and played an important role in the development and promotion of concrete poetry. In America it was also paid a considerable attention to the concrete poetry. Among the American poets who were influenced by the global process of the concrete poetry, Emit Williams, Jonathan Williams and Mary Ellen can be named. In America, Shape poetry (concrete poetry) has preserved its position and tradition by the poems that were arranged by Ezra Pound Edward Estlin Cummings. For example, Edward Estlin Cummings by the arrangement of the letter r-p-o-p-h-e-s-s-a-g-r associated a method that was first ambiguous for us and then it comes to our mind that it shows the word grasshopper. John Hollander (Various shapes, 1991), is among the prominent poets who versified shape poem whose form are associated with abstract concepts (Babaei, 2007: 75).

\subsection{The history of concrete poetry in Iran}

In Iran, Tahereh Saffarzadeh, a theorist and contemporary researchers, was the founder of the concrete poetry in Persian language. She was familiarized with concrete poetry during her stay in England and America, in addition to her broad investigation on the poets, artists and writers of those counties as well as exploration on the subject including The poetry of today's world, literary criticism, scientific criticism of translation, and documentary cinema and versifies several concrete poems in Persian following the American an English poets. She finally succeeded to present new and modern theories and definitions in the art of poetry as a result of her continuous studies to achieve the specific language of poetry. According to her view, the concrete poetry is a cooperation between a painter and poet (Saffarzadeh, 1978: 149). The poetic 
heritage of Saffarzadeh suggested the poet's long distance from new attitudes of 30s to the attitudes of modern poetry. Soon she escaped from his first home and reached the irregularity of poetic forms and patterns. Her tendency toward the western poetic form including concrete and so forth, was considered as the most prominent characteristic in her versification (Rouzbeh, 2007: 259). After Tahereh Saffarzadeh who versifies six concrete poems in the collection of "Tanin (echo)" and "Delta", Esmail Nooriala, a contemporary poet and critic, was regarded as the founder, promoter of concrete poetry in Persian language and literature. He was among the poets of New Wave poetry" and he suggested concrete poetry in 16 July 1973 in order to relieve the new wave poetry from complexities seeking to deadlock for the new wave poetic movement in the late forties and in the early fifties. Esmail Nooriala, in 1973, considered concrete poetry as the poetry of the fifties and says, “ Although the today' Iranian poetry has passed half a century, the effort of poets should be reserved for the last twenty years $(1951-1971)$. In the first decade (1951-1961) Nimai poetry was flourished, while in the second decade (1961-1971) we were faced with new wave poetry. If we seek to determine the characteristic lines in order to portrait the poetry of the third decade(1971-1981), we should consider these lines as the intersection of poetic movement of the past twenty years. When the experiences of Nimai poetry combined with innovations of new wave poetry and forms a poetic conception, it neither depends severely on the Nimai poetry, nor has the disturbance and conscious and the unconscious escapes from the description and clarification in new wave poetry. The poet of such poems attempts to express the subjective concepts clearly in the form of objectivity and the comprehension in the form of sensations (Nooriye ala, 1993: 367). The concrete poetry movement in the fifties could not fix its position due to the struggle with which people are faced in Iran against the Shah and after the Islamic revolution of Iran in 1978, like other poetry movements including new wave, blank verse, Hajm was faced with recession. While after many ups and downs, the visualization of the poetry replicated after the seventies and it can be found and identified in the language poems of Reza Baraheni, moving poems of Abulfazl Pasha, post-Nimai poems of Ali Baba-Chahi. The more we come closer to the end of the eighties, the more prominent this characteristic can be seen.

\section{Conclusion}

The result is talking about The concrete poetry is regarded as the modern poetic movements in Europe and Iran. Concrete poetry is one of the written deviations and foregrounding is associated with irregularity of poetry, graphic and sometimes calligraphic lines. In this poetic movement, the written structure is selected in such a way that the form, the structure and the combination of words, the interrupted structure of the words, the degraded form of the words into the forming letters has created visual images that play an important role in transferring the motif to the audience. Guillaume Apollinaire (1880 - 1918) played an important role in the emergence of concrete poetry. After 40 years, Apollinaire ultimately paved the way for concrete poetry by creating kind of visual poetry namely Calligram. He was influenced by the classical Iranian poets 
in versifying his Calligrams. In particular, he was influenced by Iranian acrostic poem in all its shapes including a tree, a bird, a circle and so forth. In the mid-twentieth century in the $60 \mathrm{~s}$, after the formation of international movement of Concrete poetry, the term "concrete poetry" was first known and after compiling its anthology, it was developed in 1958. in 1958, the basic principles of concrete poetry were compiled and again the Brazil was the flagship of this movement. In the early 60s, Eugen Gomringer went to Switzerland and published the concrete works of the poets in different countries of the world after the foundation of International Movement of concrete poetry. It is worth mentioning that the concrete poetry in Switzerland was developed simultaneously with the concrete poetry in Sweden by Oyvind Fahlstrom. After that, the poets of America, Mexico, Japan, Germany, Czechoslovakia and England showed the trend toward the concrete poetry. In Iran, Tahereh Saffarzadeh, a theorist and contemporary researchers, was the founder of the concrete poetry in Persian language. She was familiarized with concrete poetry during her stay in England and America, in addition to her broad investigation on the poets, artists and writers of those counties as well as exploration on the subject including The poetry of today's world, literary criticism, scientific criticism of translation, and documentary cinema and versifies several concrete poems in Persian following the American an English poets. After Tahereh Saffarzadeh, Esmail Nooriala, a contemporary poet and critic, was regarded as the founder, promoter of concrete poetry in Persian language and literature.

\section{Reference}

1. Ahmadi, R. (1995). The truth and the beauty. Tehran: Markaz

2. Anousheh, H. (1997). The literary Encyclopedia of Persian language, Vol. 2. Tehran: Printing and Publishing Ministry of Culture and Islamic Guidance.

3. Azar, E. (2008). Iranian literature in World literature, Tehran: Sokhan

4. Azarm, M., (2007). A discussion on the electronic poetry in digital area. http://tafavot.blogfa.com/86051.aspx

5. Babaei, S. (2007). Dictionary of literary terms, Tehran: Jangal Publication

6. Bateni, M. (1999). Contemporary dictionary English-Persian, 4th Edition, Tehran: Farhang-e Moaser.

7. Dad, S., (1996). Dictionary of literary terms: Glossary of the concepts of European and Persian literary terms, 2nd edition, Tehran: Morvarid Publication.

8. Gharibi, N., (2012). A review on the visual and written experiences (concrete poetry) in the contemporary Persian poetry, M.A. thesis, Persian language and literature, school of literature, Kurdistan University.

9. Honarmandi, H., (1971). New Poetry Foundation in France. First Edition. Tehran: pilgrims.

10. Hosseini, S., (1992), Niloofar-e Khamoush, Tehran: Niloofar Publication

11. Leech, G. H. A Linguistic, 1969 Guide to English Poetry, N.Y. Lonman.

12. Mahmoudi, S., (2008). Concrete Poetry and in memory of Tahereh Saffarzadeh, http://adabdan.blogfa.com/post-82.aspx 
13. Mirsadeghi, T., (1373). Art glossary poet. Tehran: Mahnaz.

14. Monshizadheh, K., (2006), Red clock in 25 hours (collection of poems), Tehran: Neghima.

15. Nooriye ala, E., (1993). The theory of poetry from New wave to love poetry, 1st edition, London, Ghazal

16. Panjei, M., (2012). Contemporary visual poetry (Poetry to Graph, pattern poetry, digital poetry, sound democracy in poetry), http://leilasadeghi.com/naghd/note/554-visual-poemmazdak.html

17. Rouzbeh, M., (2007). The Contemporary Iranian literature, 3rd edition, Tehran: Rouzegar.

18. Saffarzadeh, T., (1978). The movement and yesterday, 1st edition, Tehran: Ravagh

19. Saffarzadeh, T., (1986). The movement and yesterday, 2nd edition, Shiraz: Navid

20. Saffari, A., (2006). From the bird of acrostic poetry to the flight of concrete poetry(An introduction to concrete poetry),quarterly journal of Shere- Goharan,No. 11 \& 12, 11-17

21. Simpson, John and Edmund Weiner. (1989). Oxford English Dictionary. United Kingdom: Oxford University.

22. Shahroudi, E (Ayandeh). (1969), collection of selected poem, Bamdad Publication

23. Shamisa, S., (2004). Literary criticism, Tehran: Ferdows

24. Shamisa, S., (1993). A glance on the rhetoric, 5th edition, Tehran: Ferdows

25. Shorel, E., (1386). Comparative literature, translations doctor T. sajedi, Tehran: Amir Kabir. 